\title{
Childhood Cancer and Congenital Defects A Study of U.S. Death Certificates During the Period 1960-1966
}

\author{
R.W.MiLLeR ${ }^{[57]}$ \\ Epidemiology Branch, National Cancer Institute, Bethesda, Maryland, USA
}

\begin{abstract}
Extract
Study was made of the death certificates for all 29,457 children under 15 years of age who died of cancer in the United States during 1960-1966. Congenital defects were greatly underreported, but from the anomalies that were recorded, some new understanding of the relation between oncogenesis and teratogenesis may be derived.

On 146 death certificates, Down's syndrome was listed with leukemia, an 11 -fold excess over normal expectation. The peak mortality occurred at two years of age. In the general population, the peak occurs two years later and is due to an increase in the rates for acute lymphocytic leukemia. This study and others indicate that, contrary to popular opinion, myelogenous leukemia is not significantly more common than usual in Down's syndrome.

The association of Wilms' tumor with aniridia or renal anomalies, unknown when the death certificates were made out, was nevertheless apparent. There were previously unreported cases of leukemia with osteogenesis imperfecta, Marfan's syndrome, Treacher-Collins syndrome, and Ollier's syndrome. These cases, and others described in the literature, raise the possibility that certain genetically induced disorders of bone or connective tissue may predispose to leukemia. There were also four new cases of leukemia-lymphoma with immunological abnormality (two with myasthenia gravis; one each with ataxia-telangiectasia and agammaglobulinemia), and two with leukemia and congenital granulocytic abnormalities (one each with agranulocytosis and familial granulomatosis). Other concurrences of possible etiologic significance included two of phenylketonuria and leukemia-lymphoma, three of tetralogy of Fallot and glioma and one of cleidocranial dysostosis and medulloblastoma. Clarification of these relations may come from studies of susceptibility to viral transformation in vitro of skin fibroblasts from children with the anomalies noted above.

This study indicates that greater accuracy and completeness in filling out death certificates would greatly aid research and the clinical benefits derived from it.
\end{abstract}

\section{Speculation}

Although imperfect, diagnoses recorded on death certificates may provide clues to as yet unknown relations between cancer and congenital defects. 


\section{Introduction}

New understanding of the origins of certain childhood cancers has come from recognition of their association with specific congenital defects. A ready source of new clues to such concurrences is the recently established national registry of death certificates concerning childhood cancer. This report concerns the congenital defects found on death certificates for a 7-year interval.

\section{Methods}

The National Vital Statistics Division, U.S. Public Health Service, provided copies of death certificates for all persons under 15 years of age who died of cancer in the United States during 1960-66, except for those in Louisiana and Missouri during 1965-66. Deaths from histiocytosis were excluded. The 29,457 certificates bore the International List Numbers 140-205 [30]. Abstracted from each death certificate were demographic data, cell type of the cancer diagnosed, and all congenital anomalies listed.

The numbers of specific malformations expected by chance in our sample were estimated, insofar as possible, from published reports of the frequencies in the general population. When such data were unavailable, a disproportion was sought in the distribution of cancer deaths by type for a given class of anomalies, the normal distribution (number and relative frequency) under 15 years of age being: leukemia 14,240 (48\%), central nervous system tumors 4,680 (16\%), lymphoma 2,231 (8\%), neuroblastoma 2,093 (7 \%), Wilms' tumor 1,585 (5\%), and all other cancers 4,628 (16\%) [34].

To avoid overlooking single concurrences of potential etiological significance, evidence has been cited from the literature concerning possible links among the diseases in question. The diagnoses have not been standardized or refined, but are as given on the death certificates.

\section{Down's Syndrome}

\section{Results}

There were 146 children recorded as having Down's syndrome with leukemia, an 11-fold excess over normal expectation, but less than the 15- to 20-fold excess reported in studies with more complete ascertainment of cases [27, 51]. As in a British study [29], the peak in leukemia mortality occurred two years earlier than usual. In the general population, the peak at four years of age is due to an increase in acute lymphocytic leukemia, there being little variation in the rates for myelogenous leukemia with age during childhood [7].
Contrary to popular opinion, myelogenous leukemia is not the predominant form of the neoplasm in Down's syndrome. Studies of case series have revealed that the distribution by cell type differs little from normal $[28,29]$. Leukemia with Down's syndrome was specified as myelogenous in $13.7 \%$ of the cases in our study, as compared with $10.5 \%$ in the general population.

Among 44 children who died of leukemia under 28 days of age, eight were reported to have Down's syndrome [21]. This frequency, $1: 5.5$, is much higher than that, $1: 36$, reported for leukemia with Down's syndrome later in childhood [51]. The syndrome did not occur excessively with other neoplasms (table I, Cases 38-41).

\section{Aniridia and Wilms' Tumor (Cases 1-3)}

At the time the death certificates for 1960-64 were made out, the excessive occurrence of aniridia and Wilms' tumor was unknown. Yet three physicians recorded the anomaly on death certificates of children with the tumor (table I). The frequency of aniridia in the general population is at most 1:50,000 [49]. Finding three children with the eye defect among 1,585 with Wilms' tumor is most unlikely to be due to chance. If the relation between the two diseases were not now known [37], it would have been suggested by the death certificate study, even though aniridia was markedly underreported. Other studies $[37,48]$ have shown the rate of the defect in children with Wilms' tumor to be about 1:80. Hence, there should have been about 20 such cases in our series.

\section{Brain Defects (Cases 1, 4-37 and 42-45)}

Cerebral palsy was recorded as often with leukemia as with other cancer. Neither the array of neoplasms nor individual cases suggested an etiologic relation in the concurrences observed.

Death certificates that specified mental retardation were somewhat less common for leukemia (7 cases) than for other cancers (13 cases). Of the neoplasms involved, only the Wilms' tumor-aniridia syndrome (Case 1) is known to occur with mental retardation [37]. It is noteworthy that phenylketonuria was observed twice, though with dissimilar cancers-acute myelogenous leukemia and lymphosarcoma. Such concurrences have not been described previously, and no judgment can be made at present as to the oncogenic influence of this congenital defect or the treatment for it.

Hydrocephalus was recorded for one child with leukemia and for three with brain tumors, two of whom had multiple anomalies of the central nervous system (Cases 44 and 45 ). There is a possibility that hydrocephalus in the third child (Case 42), though specified as congenital at a university hospital, was secondary to the brain tumor. 
Table I. Congenital defects recorded on death certificates of U.S. children who died of cancer, 1960-1966, 2

\begin{tabular}{|c|c|c|c|}
\hline $\begin{array}{l}\text { Case } \\
\text { No. }\end{array}$ & Congenital defects and cancer & $\begin{array}{l}\text { Case } \\
\text { No. }\end{array}$ & Congenital defects and cancer \\
\hline & Aniridia & \multicolumn{2}{|r|}{ Down's syndrome } \\
\hline $\begin{array}{l}1 \\
2\end{array}$ & $\begin{array}{l}\text { With Wilms' tumor: } \\
\text { M.R. (M,5) } \\
\text { Aplastic kidney; congenital dislocated hip } \\
{[25](F, 1)} \\
\text { Aplastic kidney }(M, 1)\end{array}$ & $38-41$ & $\begin{array}{l}\text { With neoplasia other than leukemia: } \\
4 \text { cases; } 1 \text { each with lymphoblastic } \\
\text { lymphoma and AL }(\mathrm{M}, 4) \text {; Ewing's tumor } \\
\text { and L, NOS }(\mathrm{F}, 7) \text {; neuroblastoma } \\
(\mathrm{M}, 5 \mathrm{~m}) ; \text { retinoblastoma }(\mathrm{M}, 1)\end{array}$ \\
\hline & Cerebral palsy & \multicolumn{2}{|r|}{ Hydrocephalus; neural-tube defects } \\
\hline $4-11$ & $\begin{array}{l}\text { With leukemia: } \\
8 \text { cases }(7 \mathrm{M}: 1 \mathrm{~F}, 5-14) ; 2 \text { with quadriple- } \\
\text { gia and M.R. } \\
\text { With other neoplasia: }\end{array}$ & 42 & $\begin{array}{l}\text { With leukemia: } \\
\text { Hydrocephalus (M,1) } \\
\text { With other neoplasia: }\end{array}$ \\
\hline $12-19$ & $\begin{array}{l}8 \text { cases; } 2 \text { with neuroblastoma }(M, 4 ; M, 7) \text {, } \\
\text { and } 1 \text { each with Hodgkin's disease }(\mathrm{M}, 11) \text {; } \\
\text { medulloblastoma }(\mathrm{F}, 8) \text {; fibrosarcoma, } \\
\text { posterior fossa }(\mathrm{F}, 9) ; \text { congenitally dis- } \\
\text { located hips with retinoblastoma }(\mathrm{F}, 3) \text {; } \\
\text { spastic quadriplegia and M.R. with } \\
\text { sclerosing metastic hemangioma of gums } \\
(\mathrm{M}, 6) \text {; and carcinoma of jaw, NOS }(\mathrm{M}, 9) \text {. }\end{array}$ & 45 & $\begin{array}{l}\text { brain tumor }(\mathrm{M}, 6) \\
\text { Hydrocephalus, congenital porencephaly, } \\
\text { agenesis of corpus callosum, infantile } \\
\text { spasm, M.R. with malignant tumor of } \\
\text { cervical lymph gland (F,2) } \\
\text { Arnold-Chiari deformity with malignant } \\
\text { brain tumor }(\mathrm{F}, 5) \\
\text { Meningocele with cancer of the lung, } \\
\text { NOS (F, } 4)\end{array}$ \\
\hline & $\begin{array}{l}\text { Mental retardation } \\
\text { With leukemia (see also Cases } 4 \text { and 5): }\end{array}$ & & Cranial and/or facial dysostosis (see also Case 20) \\
\hline $20-26$ & $\begin{array}{l}7 \text { cases }(4 \mathrm{M}: 3 \mathrm{~F}, 2-14) ; 1 \text { with congenital } \\
\text { microcephaly and ALL }(\mathrm{F}, 12) \text { and } 1 \text { with } \\
\text { phenylketonuria and AML (F,14) } \\
\text { With other neoplasia (see also Cases, } 1,18 \\
\text { and } 44) \text { : }\end{array}$ & $\begin{array}{l}47 \\
48\end{array}$ & $\begin{array}{l}\text { With leukemia: } \\
\text { Craniosynostosis with AL (F, 10m) } \\
\text { Treacher-Collins syndrome with AMoL } \\
(\mathrm{M}, 2) \\
\text { With other neoplasia: }\end{array}$ \\
\hline $\begin{array}{r}27-37 \\
:\end{array}$ & $\begin{array}{l}11 \text { cases; } 1 \text { each with phenylketonuria and } \\
\text { lymphosarcoma }(\mathrm{F}, 14) \text {; absence of corpus } \\
\text { callosum and malignant lymphoma } \\
(\mathrm{F}, 11) \text {; malignant lymphoma and LL } \\
(\mathrm{M}, 14) \text {; lymphosarcoma }(\mathrm{M}, 10) \text {; cerebral } \\
\text { defect due to maldevelopment with pos- } \\
\text { sible lymphoma }(\mathrm{F}, 3) \text {; astrocytoma } \\
(\mathrm{M}, 3) \text {; blind, deaf, epilepsy, I.Q. = } 17 \\
\text { with astrocytoma }(\mathrm{M}, 9) ; \text { retinoblastoma } \\
(\mathrm{F}, 3) \text {; neuroblastoma }(\mathrm{M}, 1) \text {; papillary }\end{array}$ & $\begin{array}{l}50 \\
51 \\
52\end{array}$ & $\begin{array}{l}\text { Cleft lip/palate, hypertelorism, syndactyly, } \\
\text { platybasia with reticulum cell sarcoma } \\
\text { (M,2) } \\
\text { Cleft lip with neuroblastoma }(\mathrm{F}, 6) \\
\text { Cleidocranial dysostosis with medullo- } \\
\text { blastoma }(\mathrm{F}, 7) \\
\text { Pierre-Robin syndrome with retino- } \\
\text { blastoma }(\mathrm{F}, 2) \\
\text { Other skeletal defects }\end{array}$ \\
\hline & $\begin{array}{l}\text { carcinoma of kidney }(\mathrm{M}, 9) \text {; carcinoma of } \\
\text { lung, NOS }(\mathrm{F}, 2) \text {. }\end{array}$ & 53 & $\begin{array}{l}\text { With leukemia (see also Cases } 61 \text { and } 143 \text { ) } \\
\text { Marfan's syndrome with AL }(F, 9)\end{array}$ \\
\hline
\end{tabular}

1 Excludes 146 with Down's syndrome and leukemia.

${ }^{2}$ Abbreviations : $\mathrm{m}=$ months; $\mathrm{d}=$ days; $\mathrm{NOS}=$ not otherwise specified; M.R. = mental retardation; types of leukemia $(\mathrm{L}): \mathrm{AL}=$ acute $\mathrm{LL}=$ lymphocytic; $\mathrm{ML}=$ myelogenous $\mathrm{MoL}=$ monocytic; $\mathrm{SCL}=$ stem cell.

${ }^{3}$ Sex and age in years. 
Table I. (Continued)

\begin{tabular}{|c|c|c|c|}
\hline $\begin{array}{l}\text { Case } \\
\text { No. }\end{array}$ & Congenital defects and cancer & $\begin{array}{l}\text { Case } \\
\text { No. }\end{array}$ & Congenital defects and cancer \\
\hline 54 & Marfan's syndrome with SCL $[14](\mathrm{M}, 1 \mathrm{I})$ & & With other neoplasms: \\
\hline 55 & $\begin{array}{l}\text { Osteogenesis imperfecta with } \mathrm{L}, \mathrm{NOS} \\
(\mathbf{F}, 2)\end{array}$ & 75 & $\begin{array}{l}\text { Muscular dystrophy with cerebellar tumor } \\
(\mathrm{M}, 13)\end{array}$ \\
\hline 56 & $\begin{array}{l}\text { Ollier's syndrome with AML (F, 7) } \\
\text { With other neoplasia (see also Cases } 2 \text { and } \\
\text { I7): }\end{array}$ & 76 & $\begin{array}{l}\text { Muscular dystrophy with embryonal } \\
\text { rhabdomyosarcoma }(\mathrm{M}, 13)\end{array}$ \\
\hline 57 & $\begin{array}{l}\text { Chondrodystrophy with neuroblastoma } \\
(\mathrm{M}, 4)\end{array}$ & & $\begin{array}{l}\text { Heart defects } \\
\text { With leukemia: }\end{array}$ \\
\hline 58 & $\begin{array}{l}\text { Chondrodystrophy with Wilms' tumor } \\
(\mathrm{F}, 4)\end{array}$ & $\begin{array}{l}77-78 \\
79\end{array}$ & $\begin{array}{l}2 \text { with I-A septal defects }(2 \mathrm{M}, 2,3) \\
\text { Ostium primum }(\mathrm{F}, 1)\end{array}$ \\
\hline 59 & Dysplasia of hips with teratoma $(F,<1 d)$ & $80-86$ & 7 with $\mathrm{I}-\mathrm{V}$ septal defects $(5 \mathrm{M}: 2 \mathrm{~F}, 1-11)$ \\
\hline 60 & $\begin{array}{l}\text { Platybasia with astrocytoma of optic nerve } \\
(\mathrm{M}, 12)\end{array}$ & $\begin{array}{l}87 \\
88\end{array}$ & $\begin{array}{l}\text { Tetralogy of Fallot }(\mathbf{M}, 9) \\
\text { Pulmonary stenosis }(\mathbf{F}, 3)\end{array}$ \\
\hline & Hematologic defects & 89 & $\begin{array}{l}\text { Congenital heart disease, patent foramen } \\
\text { ovale }(\mathrm{F}, \mathrm{I})\end{array}$ \\
\hline 61 & $\begin{array}{l}\text { With leukemia: } \\
\text { Fanconi's aplastic anemia with L, NOS } \\
{[20](M, 8)}\end{array}$ & $90-92$ & $\begin{array}{l}3 \text { with congenital heart disease, NOS } \\
(2 \mathrm{M}: 1 \mathrm{~F}, 3-6) \\
\text { With other neoplasia (see also Case } 122 \text { ): }\end{array}$ \\
\hline 62 & $\begin{array}{l}\text { Congenital agranulocytosis with AMoL } \\
(\mathrm{M}, 14)\end{array}$ & $\begin{array}{l}93 \\
94-96\end{array}$ & $\begin{array}{l}\text { Tetralogy of Fallot with hepatoma }(\mathrm{M}, 9) \\
3 \text { with tetralogy of Fallot and glioma }\end{array}$ \\
\hline 63 & $\begin{array}{l}\text { Familial granulomatosis with } \mathrm{L}, \text { NOS } \\
(\mathrm{M}, 10) \\
\text { With other neoplasia: }\end{array}$ & 97 & $\begin{array}{l}(3 \mathrm{M}, 7-13) \\
\text { Ventricular cardiac shunt with glioma } \\
(\mathrm{F}, 3)\end{array}$ \\
\hline 64 & $\begin{array}{l}\text { Chediák-Higashi syndrome with mal- } \\
\text { ignant lymphoma }[31](\mathrm{M}, 3)\end{array}$ & 98 & $\begin{array}{l}\text { Transposition of great vessels with Wilms' } \\
\text { tumor }(M, 6)\end{array}$ \\
\hline 65 & $\begin{array}{l}\text { Hemophilia A with adenocarcinoma of } \\
\text { testicle }(M, 6)\end{array}$ & 99 & $\begin{array}{l}\text { Fibroelastosis with fibrosarcoma of } \\
\text { posterior fossa (M, } 3 \mathrm{~m})\end{array}$ \\
\hline $\begin{array}{l}66 \\
67\end{array}$ & $\begin{array}{l}\text { Hemophilia A with astrocytoma (M,2) } \\
\text { Hemophilia with neuroblastoma (M,4) }\end{array}$ & 100 & $\begin{array}{l}\text { Patent foramen ovale with leiomyosar- } \\
\text { coma }(F, 11)\end{array}$ \\
\hline 68 & $\begin{array}{l}\text { Sickle cell disease with Wilms' tumor } \\
(\mathrm{M}, 3)\end{array}$ & 101 & $\begin{array}{l}\text { Hypoplasia of mitral leaflet with Wilms' } \\
\text { tumor }(F, 5 \mathrm{~m})\end{array}$ \\
\hline 69 & $\begin{array}{l}\text { Sickle cell anemia with Letterer-Siwe } \\
\text { disease }(F, 2)\end{array}$ & 102 & $\begin{array}{l}\text { Pulmonary stenosis with Kaposi's sarcoma } \\
(\mathrm{M}, 18 \mathrm{~d})\end{array}$ \\
\hline & Immunologic defects & 103 & $\begin{array}{l}\text { Pulmonary stenosis with Hodgkin's disease } \\
(\mathrm{M}, 8)\end{array}$ \\
\hline 70 & $\begin{array}{l}\text { With leukemia: } \\
\text { Agammaglobulinemia with } \mathrm{L}, \text { NOS } \\
(\mathrm{M}, 10)\end{array}$ & 104 & $\begin{array}{l}\text { Pulmonary stenosis, } \mathrm{I}-\mathrm{V} \text { septal defect and } \\
\text { dilated } \mathrm{rt} \text {. aorta with neuroblastoma } \\
(\mathrm{M}, 10 \mathrm{~m})\end{array}$ \\
\hline 71 & $\begin{array}{l}\text { Myasthenia gravis with chronic LL }(F, 13) \\
\text { With other neoplasms: }\end{array}$ & 105 & $\begin{array}{l}\text { Coarctation of aorta and patent ductus } \\
\text { with neuroblastoma }(F, 8)\end{array}$ \\
\hline 72 & $\begin{array}{l}\text { Myasthenia gravis with lymphosarcoma } \\
(\mathrm{M}, 14)\end{array}$ & $106-109$ & $\begin{array}{l}4 \text { with congenital heart disease, NOS, } \\
\text { and neuroblastoma }(2 \mathrm{M}: 2 \mathrm{~F}, 6-10)\end{array}$ \\
\hline 73 & $\begin{array}{l}\text { Ataxia-telangiectasia with lymphosar- } \\
\text { coma of pharynx }(\mathrm{M}, 11)\end{array}$ & & Cystic fibrosis of the pancreas \\
\hline & $\begin{array}{l}\text { Muscular } \\
\quad \text { With leukemia }\end{array}$ & $110-112$ & $\begin{array}{l}\text { With leukemia: } \\
3 \text { cases }(2 \mathrm{M}: 1 \mathrm{~F}, 1 \mathrm{~m}-5) \\
\text { With other neoplasia: }\end{array}$ \\
\hline 74 & Muscular dystrophy with AL (M, 11) & $113-114$ & 2 with Wilms' tumor $(\mathbf{M}, 2 ; \mathrm{F}, 2)$ \\
\hline
\end{tabular}


Table I. (Continued)

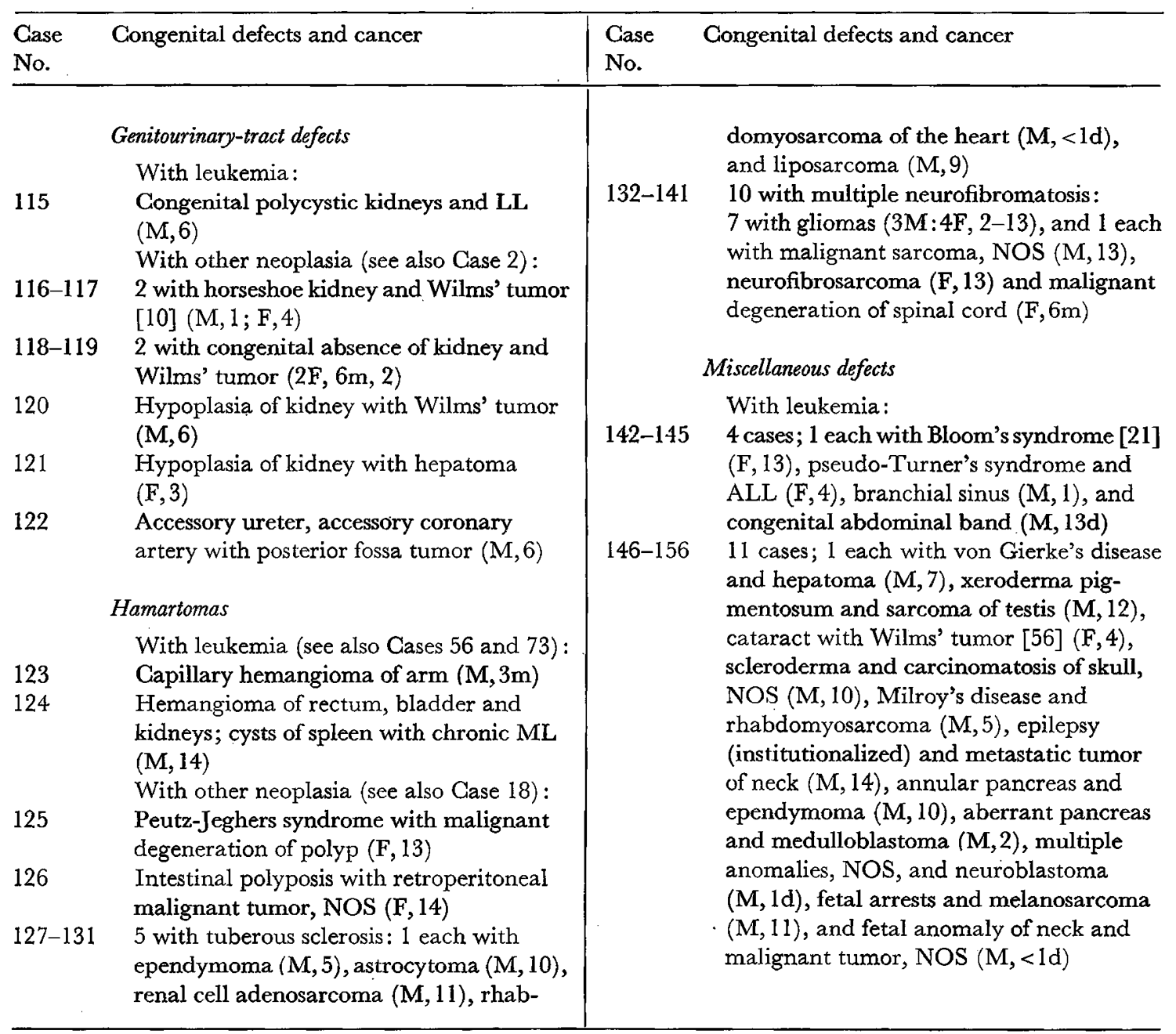

Cranial and/or Facial Dysostoses (Cases 20 and 47-52)

Of special interest was the occurrence of brain tumor with cleidocranial dysostosis, a syndrome in which cerebral maldevelopment occurs [14], and of retinoblastoma with Pierre-Robin syndrome, a disorder with a high frequency of brain and ocular abnormalities [50].

Other Skeletal Defects (Cases 53-61, 142 and 143)

The frequency of general skeletal abnormalities in our series was too small to show any definitive association with neoplasia, but in conjunction with case reports in the literature, there is reason to suspect that certain genetically induced disorders of bone may carry an increased risk of leukemia. The death certificates revealed that two children with Marfan's syndrome had leukemia; one of them had been reported by REIsMAN et al. [46]. Our case with osteogenesis imperfecta was the third described with leukemia, the other two having been siblings [23]. The occurrence of leukemia with Ollier's syndrome (osteochondromatosis) in our study is the first known to us. Perhaps in the same category are previously reported cases of myelogenous leukemia in a newborn with Klippel-Feil syndrome [2] and in another with a possible variant of the Ellis-van Creveld syndrome [33], as well as cases of acute lymphocytic leukemia in one child with achondroplasia [18] and in another with the xerodermic idiocy of de Sanctis and Cacchrone [45].

In our study the child with Fanconi's aplastic ane- 
mia and leukemia (Case 61) had been reported by Buoom et al. [3]. Their description indicates that in this child, as in the other three known to date $[3,12$, 24], the leukemia was of the acute monocytic type. The influence of chance on these concurrences may be clarified by determining if children with the abovementioned anomalies exhibit increased susceptibility of their skin fibroblasts in culture to transformation by the oncogenic virus, SV 40 . Increased susceptibility has been demonstrated in the homozygote and in the heterozygote for Fanconi's anemia and, to a lesser extent, for Down's syndrome, anomalies with dissimilar chromosomal aberrations and a predisposition to leukemia [40].

\section{Hematologic Abnormalities (Cases 61-69)}

In addition to Fanconi's anemia, two other congenital blood dyscrasias - agranulocytosis and familial granulomatosis-were recorded on death certificates of children with leukemia. To our knowledge, neither anomaly has been reported previously in persons with neoplasia, but myelogenous leukemia has been described twice in siblings of persons with hereditary neutropenia $[10,56]$. Lymphosarcoma has been reported in three persons with cyclical neutropenia [41]. These inborn blood dyscrasias may mimic leukemia [8], or leukemia may induce a hematologic disorder that mimics them. Neither error seems to have been made in the cases cited above from the literature nor in our series on the death certificate for a 14-year-old boy who died of congenital agranulocytosis at a leading university hospital. He had acute monocytic leukemia, the same type seen in Fanconi's anemia. In this connection, one wonders if, as in all leukemia-prone conditions known to date [35], congenital neutropenia also exhibits chromosomal abnormalities. Data are limited to several cytogenetic aberrations described in a single case of hereditary infantile agranulocytosis (Kostmann's disease) [31].

Malignant lymphoma with Chediák-Higashi syndrome, a disorder characterized by granulocyte abnormalities [4], was recorded on the death certificate of a child previously described by PAGE et al. [43]. Other case reports attest to the malignant nature of the neoplasia [9] and indicate that its occurrence in children with the syndrome is unlikely to be due to chance [19]. The syndrome has not been reported with leukemia.

Hemophilia was noted on three death certificates as compared with the two expected if there had been no underreporting. The frequency of hemophilia has been estimated to be $1.44 / 10,000$ males under 19 years of age [26]. The dissimilarity in the neoplasms observed, however, suggests that the presence of these growths was fortuitous.

\section{Immunological Defects (Cases 70-73)}

There is mounting evidence that genetic immunological disorders predispose to lymphoma and, less so, to leukemia [19]. The death certificate survey revealed previously unreported cases of agammaglobulinemia with leukemia of unspecified type and ataxia-telangiectasia with lymphosarcoma of the pharynx. Perhaps in a related category is myasthenia gravis, which occurred in one child with chronic lymphocytic leukemia and in another with Iymphosarcoma. Only one case of the former has been reported previously [6]. The excessive occurrence of myasthenia gravis with thymoma has been well established by other investigators [44].

\section{Muscular Disorders (Cases 74-76)}

Muscular dystrophy was noted in three adolescent boys with neoplasms, the dissimilarity of which suggests chance occurrence.

\section{Congenital Heart Disease (Cases 77-109 and 122)}

The distribution of neoplasms in 34 children with cardiac anomalies did not differ from normal expectation. Certain classes of heart defects, however, tended to occur with specific neoplasms. Among ten children with septal defects and cancer, five would be expected to have leukemia, but all ten did. There was a deficiency of leukemia in children with other forms of congenital heart disease. Among 24 children with cancer, only six had leukemia. The difference in the two distributions is highly significant statistically $(p<0.0004$; Fisher's exact test), but the groupings may be regarded as contrived since various forms of congenital heart disease, from the very complex to isolated septal defects, may have origins in common. Thus, autopsies of 272 'children with Down's syndrome, which predisposes to leukemia, revealed 20 types of cardiac malformation [52].

Tetralogy of Fallot was another anomaly with an unusual array of neoplasms: three gliomas, one hepatoma and one leukemia. There is no direct evidence in the literature concerning high risk of cancer in tetralogy of Fallot. There is, however, a constellation of diseases through which the two diseases may be linked. It includes multiple neurofibromatosis, glioma, pheochromocytoma and congenital heart disease [36]. Furthermore, neurofibromatosis has been observed in two children with coarctation of the aorta [13], and at least one other case has been reported in the voluminous literature on von Recklinghausen's disease [54]. A possible forme fruste of neurofibromatosis in which there are multiple café-au-lait spots, dull intelligence and familial pulmonic stenosis has been described [54]. These observations indicate that as series of children with cardiac anomalies are followed over a period of time at large medical centers, and as their survival 
rates increase, it would be of interest to evaluate the frequency of disorders related to neurofibromatosis [36].

There were seven deaths from neuroblastoma in children with congenital heart disease as compared with 2.4 expected $(7 \%$ of 34 children with cardiac defects). Study of 502 hospital records of children with neuroblastoma [38] revealed six with congenital heart disease. This frequency was not significantly greater than expectation (5.5/1,000 grammar school children [42]). At present it appears that congenital heart disease is associated with little, if any, increased risk of neuroblastoma.

Cystic Fibrosis of the Pancreas (Cases 110-114)

Cystic fibrosis of the pancreas (CF) was reported in three children with leukemia and in two with Wilms' tumor. Since about 2,000 children are born each year with GF [11] and about half survive until 10 years of age [53], 70,000-100,000 child-years-at-risk are involved in children under 15 years of age during a 7-year interval. Thus, five to seven children with CF would be expected to die of neoplasia by chance. In future studies of mortality pertaining to $\mathrm{CF}$, the possible leukemogenic influence of chloramphenicol treatment should be considered $[5,16]$.

Genitourinary Anomalies (Cases 2 and 115-122)

Of the eight children with kidney anomalies, six had Wilms' tumor, an excess in agreement with the established association between the neoplasm and renal malformations [37].

\section{Hamartomas (Cases 18, 56, 73 and 123-141)}

The well-known predisposition to cancer in hamartomatous syndromes $[32,55]$ was reflected in death certificates for five children with tuberous sclerosis, ten with multiple neurofibromatosis and two with intestinal polyposis. One other child had had sclerosing metastatic hemangioma of the gum (Case 18). Two children had hemangiomas and leukemia (Cases 123 and 124), and one, already discussed, had osteochondromatosis and leukemia (Case 56). Previous observations indicate a relation between hamartomas and Wilms' tumor [39] and between hamartomas and adrenocortical neoplasia [22].

\section{Miscellaneous Defects (Cases 142-156)}

Bloom's syndrome in one child who died of leukemia (case 142) together with two other such cases, have been reported previously by SAwITSKY et al. [47]. The syndrome, in common with Fanconi's anemia, displays excessive chromosomal fragility in culture, a feature of possible importance in oncogenesis [47]. The cell type of leukemia in Bloom's syndrome, con- trary to that in Fanconi's anemia, has not been monocytic [47].

One girl with a death certificate diagnosis of 'pseudoTurner's syndrome', made at a university hospital, had acute lymphocytic leukemia. There is no reason at present, however, to suspect an increased risk of leukemia in this syndrome.

Preexistent discase of the liver apparently predisposes to neoplasia of that organ in childhood [20]. Our case with von Gierke's disease and hepatoma, not previously reported, is the third known to us.

\section{Discussion}

The death certificates indicated that cancer in childhood is largely diagnosed at major medical centers. The percentage will vary from one area to another. Our data revealed, for example, that more than $75 \%$ of children who died of cancer in Los Angeles County were seen at a university hospital. In two recent British studies $[1,25]$, the diagnosis of childhood cancer on death certificates showed only an $11 \%$ discrepancy from that on hospital charts.

Listing congenital defects on death certificates of children who die of cancer will depend in part on the physician's knowledge that the two diseases are related and on the lethality of the congenital abnormality. Thus, as the physician makes out the death certificate for a child with leukemia and Down's syndrome, he is likely to recall that the two diseases are linked, or, when a child has died of cancer and hemophilia or GF, he may record the congenital defects because these can be lethal alone. In contrast, cleft lip/palate, which is in neither of these categories, was recorded on only two death certificates of children with cancer, as compared with about 50 expected. In this instance, the possibility that the anomaly may be associated with resistance to cancer cannot be excluded. Gertain cancers may, of course, be related to congenital defects even though no such concurrences were recorded on the death certificates, as, for example, Wiskott-Aldrich syndrome with lymphoreticular neoplasia or Wilms' tumor with hemihypertrophy $[19,39]$.

It is unfortunate that physicians do not regularly follow the simple practice of listing on death certificates significant diseases other than the underlying cause of death. If they did so, relations that involve diseases too rare to be studied on anything less than a national scale might be recognized. Screening of death certificates is simple and can be carried out anywhere in the world, since no special equipment is needed.

Several of the death certificates recorded relations between congenital defects and cancer of considerable clinical and research interest. Failure of the attending 
physicians to publish brief descriptions and interpretations of these remarkable cases may delay progress in understanding the diseases involved.

\section{References and Notes}

1. Alderson, M.R. and Meade, T.W.: Accuracy of diagnosis on death certificates compared with that in hospital records. Brit.J.prev.soc. Med. 21: 22 (1967).

2. Bernhard, W.G.; Gore, I. and Kilby, R.A.: Congenital leukemia. Blood 6: 990 (1951).

3. Bloom, G.E.; Warner, S.; Park, S.G. and DiaMOND, L.D.: Chromosome abnormalities in constitutional aplastic anemia. New Engl.J. Med. 274: 8 (1966).

4. Blume, R.S.; Bennett, J.M.; Yankee, R.A. and WOLFF, S. M. : Defective granulocyte regulation in the Chediak-Higashi syndrome. New Engl.J.Med. 279: 1009 (1968).

5. Brauer, M.J. and Dameshex, W.: Hypoplastic anemia and myeloblastic leukemia following chloramphenicol therapy. Report of three cases. New Engl.J. Med. 277: 1003 (1967).

6. Cohen, S. M. and WAXman, S.: Myasthenia gravis, chronic lymphocytic leukemia, and autoimmune hemolytic anemia. 'A spectrum of thymic abnormalities?' Arch.intern. Med. 120: 717 (1967).

7. Court Brown, W.M. and Doll, R.: Leukaemia in childhood and young adult life: Trends in mortality in relation to aetiology. Brit.med.J. $i$ : 981 (1961).

8. Gutting, H.O. and Lang, J.E.: Familial benign chronic neutropenia. Ann.intern.Med. 61: 876 (1964).

9. Dent, P. B.; Fish, L. A.; White, J. G. and Good, R.A.: Chediak-Higashi syndrome. Observations on the nature of the associated malignancy. Lab. Invest. 15: 1634 (1966).

10. De Vrtes, A.; Peketh, L. and Joshua, H: : Leukaemia and agranulocytosis in a member of a family with hereditary leukopenia. Acta med.orient. 27: 26 (1958).

11. DI SANT'Agnese, P.A.: Pathogenesis and physiopathology of cystic fibrosis of the pancreas. Fibrocystic disease of the pancreas (mucoviscidosis). New Engl.J. Med. 277: 1287 (1967).

12. Dosik, H.; Hsu, L.Y.; Todaro, G.J.; LeE, S. L.; Hirschiorn, K.; Selirio, E.S. and Alter, A.A.: Malignant transformation in Fanconi's anemia. Clin. Res. (Abstr.) 17: 324 (1969).

13. Engle, M.A.: Personal communication.

14. Epstern, J.A. and Epstein, B.S.: Deformities of the skull surfaces in infancy and childhood. J. Pediat. 70: 636 (1967).

15. Fontana, V.J.; Ferrara, A. and Perciacaante, R.: Wilms' tumor and associated anomalies. Amer. J.Dis. Child. 109: 459 (1965).

16. FraUmeni, J.F., Jr.: Bone marrow depression induced by chloramphenicol or phenylbutazone. J. amer.med. Ass. 201: 828 (1967).

17. Fraument, J. F., Jr. and Glass, A.G.: Wilms' tumor and congenital aniridia. J. amer. med. Ass. 206: 825 (1968).

18. Fraumeni, J.F., Jr. and Manning, M.D.: Achondroplasia and leukemia. Brit. med.J. ii: 680 (1967).

19. FrAUMENI, J.F., Jr. and Miller, R.W.: Epidemiology of human leukemia: Recent observations. J.nat. Cancer Inst. 38: 593 (1967).

20. Fraumeni, J.F., Jr.; Miller, R.W. and Hill, J.A.: Primary carcinoma of the liver in childhood: An epidemiologic study. J. nat. Cancer Inst. 40: 1087 (1968).

21. Fraumeni, J.F., Jr. and Miller, R.W.: Cancer deaths in the newborn. Amer. J. Dis. Child. 117: 186 (1969).

22. Fraument, J.F., Jr. and Mrller, R.W.: Adrenocortical neoplasms with hemihypertrophy, brain tumors, and other disorders. J.Pediat. 70:129(1967).

23. Grlchrist, G.S. and Shore, N.A.: Familial leukemia and osteogenesis imperfecta. J.Pediat. 71: 115 (1967).

24. GMYREK, D.; WitKoWsKI, R.; SYLlm-Rapoport, I. and JACOBASCH, G.: Chromosomal aberrations and abnormalities of red-cell metabolism in a case of Fanconi's anaemia before and after development of leukemia. German med. Mthl. (English-language edition) 13: 105 (1968).

25. Heasman, M.A. and Lipworth, L.: Accuracy of certification of cause of death. Great Britain, General Register Office, Studies on Medical and Population Subjects No.20. (Her Majesty's Stationary Office, London 1966.)

26. Hewits, D. and Mruner, J.: Prevalence of haemophilia in Ontario, 1966. (To be published.)

27. Holland, W.W.; Doll, R. and Car'ter, G. O.: The mortality from leukaemia and other cancers among patients with Down's syndrome (mongols) and among their parents. Brit.J. Cancer 16: 177 (1962).

28. Jackson, E.W.; Turner, J.H.; Klauber, M.R. and NorRIs, F.D.: Down's syndrome: Variation of leukemia occurrence in institutionalized populations. J.chron. Dis. 21: 247 (1968).

29. LASHOF, J.C. and Stewart, A.: Oxford survey of childhood cancers. Progress report III : Leukaemia and Down's syndrome. Mthl. Bull. Minist. Hlth 24: 136 (1965). 
30. Manual of the international statistical classification of diseases, injuries and causes of death; 7th revision (WHO, Geneva 1967).

31. Matsaniotrs, N.; Kiossoglou, K.A.; Karpouzas, J. and Anastasea-Vlachou, K.: Chromosomes in Kostmann's disease. Lancet ii: 104 (1966).

32. McKusick, V.A.: Genetic factors in intestinal polyposis. J.amer.med.Ass. 182: 271 (1962).

33. Mrller, D. R.; Newstead, G.J. and Young, L.W.: Perinatal leukemia with a possible variant of the Ellis-van Creveld syndrome.J.Pediat.74: 300 (1969).

34. MrLLER, R.W.: 52 forms of childhood cancer: U.S. mortality experience, 1960-66. J. Pediat. (in press).

35. Muller, R.W.: Persons at exceptionally high.risk of leukemia. Gancer Res. 27: 2420 (1967).

36. MrlleR, R.W.: Wilms' tumor, congenital heart defects, pheochromocytomas and thyroid cancer. Amer.J.Dis. Ghild. 116: 564 (1968).

37. Mrller, R.W.; Fraumeni, J.F., Jr. and Manning, M.D.: Association of Wilms' tumor with aniridia, hemihypertrophy and other congenital malformations. New Engl.J. Med. 270: 922 (1964).

38. Muller, R.W.; Fraumeni, J.F., Jr. and Hril, J.A.: Neuroblastoma: Epidemiologic approach to its origin. Amer.J. Dis. Child 115: 253 (1968).

39. MILLER, R.W.: Relation between cancer and congenital defects: An epidemiologic evaluation. J. nat. Gancer Inst. 40: 1079 (1968).

40. Miller, R.W. and Todaro, G.J.: Viral transformation of cells from persons at high risk of cancer. Lancet $i$ : 81 (1969).

41. Morlex, A.A.; Garew, J.P. and Baikie, A.G.: Familial cyclical neutropenia. Brit.J.Haemat. 13: 719 (1967).

42. Morton, W.: Heart disease prevalence in school children in two Golorado communities. Amer.J. publ.Hlth 52: 991 (1962).

43. Page, A. R.; Berendes, H.; Warner; J. and Good, R. A.: The Chediák-Higashi syndrome. Blood 20: 330 (1962).

44. Perlo, V.P.; Sahwab, R.S. and Castleman, B.: Myasthenia gravis and thymoma; in W. Brarn and F.H. NorRIs, Jr. The remote effects of cancer on the nervous system; vol. 1, p.55 (Grune and Stratton, New York 1965).
45. Reed, W.B.; Landing, B.; Sugarman, G.; Gleaver, J.E. and Melnyk, J.: Xeroderma pigmentosum. Clinical and laboratory investigation of its basic defect. J.amer.med.Ass. 207: 2073 (1969).

46. Reisman, L.E.; Mrtani, M. and Zuelzer, W.: Chromosome studies in leukemia. I. Evidence for the origin of leukemia stem lines from aneuploid mutants. New Engl.J. Med. 270: 591 (1964).

47. Sawitsky, A.; Bloom, D. and German, J.: Chromosomal breakage and acute leukemia in congenital telangiectatic erythema and stunted growth. Ann. intern. Med. 65: 487 (1966).

48. Sarweisguth, O.; Campinchi, R.; Prvoteau, B. et LEMERLE, J.: L'association aniridie-tumeur du rein chez l'enfant. A propos de 4 cas. Bull. Soc. Ophtal.France. 67: 1099 (1967).

49. Shaw, M.W.; Falls, H.F. and NeEl, J.V.: Congenital aniridia. Amer.J.hum. Genet. 12: 389 (1960).

50. Smith, J.L. and Stowe, F.R.: The Pierre Robin syndrome (glossoptosis, micrognathia, cleft palate). A review of 39 cases with emphasis on associated ocular lesions. Pediatrics 27: 128 (1961).

51. Stewart, A.; WebB, J. and Hewtrt, D.: A survey of childhood malignancies. Brit.med.J. i: 1495 (1958).

52. Warkany, J.; Passarge, E. and Smith, L. B. : Congenital malformations in autosomal trisomy syndromes. Amer. J. Dis. Child. 112: 502 (1966).

53. WARwick, W.J.: Cystic fibrosis. Nature and prognosis. Minnesota Med. 50: 1049 (1967).

54. Watson, G.H.: Pulmonary stenosis, cafe-au-lait spots, and dull intelligence. Arch. Dis. Childh. 42: 303 (1967).

55. Willis, R. A.: The borderland of embryology and pathology, p.351 (Butterworth, London 1958).

56. Wolff, E.: Agranulozytose und Myeloblastenleukämie als Reaktionsformen auf denselben Infekt bei zwei Geschwistern. Folia haemat. 44: 38 (1931).

57. Requests for reprints should be addressed to: RoBERT W. MILler, M.D., National Institutes of Health, NCI, Wiscon Building, Room 402 A, Bethesda, Maryland 20014, USA. 